\title{
Combined Detection of Lymphocyte Clonality and MALT1 Translocations in Bronchoalveolar Lavage Fluid for Diagnosing Pulmonary Lymphomas: A Multicenter Study of a Rare Disease Group
}

Takashi Kido ( $\nabla$ t-kido@nagasaki-u.ac.jp )

Nagasaki University https://orcid.org/0000-0001-8338-0608

Hiroshi Ishimoto

Nagasaki University

Hiroshi Ishii

Fukuoka Daigaku Chikushi Byoin

Kanako Hara

University of Occupational and Environmental Health Japan: Sangyo Ika Daigaku

Hiroki Kawabata

University of Occupational and Environmental Health Japan: Sangyo Ika Daigaku

Toshinori Kawanami

University of Occupational and Environmental Health Japan: Sangyo Ika Daigaku

Yu Suzuki

Kokura Kinen Byoin

Hiroki Yoshikawa

Oita University: Oita Daigaku

Atsuko Hara

Nagasaki Daigaku

Noriho Sakamoto

Nagasaki Daigaku

Nobuhiro Matsumoto

Miyazaki Daigaku

Chiharu Yoshii

Wakamatsu Hospital of the University of Occupational and Environmental Health: Sangyo Ika Daigaku Wakamatsu Byoin

Masaki Fujita

Fukuoka University Hospital: Fukuoka Daigaku Byoin

Masamitsu Nakazato

Miyazaki Daigaku

Junichi Kadota 
Oita Daigaku

\section{Hiroshi Mukae}

Nagasaki Daigaku

\section{Kazuhiro Yatera}

University of Occupational and Environmental Health Japan: Sangyo Ika Daigaku

\section{Research}

Keywords: bronchoalveolar lavage fluid, immunoglobulin $\mathrm{H}$ gene rearrangement, lymphocyte clonality, mucosa-associated lymphoid tissue lymphoma, pulmonary lymphoma, $\mathrm{T}$ cell receptor

Posted Date: May 5th, 2021

DOl: https://doi.org/10.21203/rs.3.rs-460537/v1

License: (c) (1) This work is licensed under a Creative Commons Attribution 4.0 International License. Read Full License 


\section{Abstract \\ Background}

The diagnosis of pulmonary lymphoma using small tissue samples is difficult and often requires surgical procedures; thus, a less invasive sampling method is desirable. We previously showed that pulmonary mucosa-associated lymphoid tissue (MALT) lymphoma could be diagnosed by detecting MALT lymphoma translocation gene 1 (MALT1) translocations in bronchoalveolar lavage fluid (BALF) cells. Analysis of B-cell clonality based on immunoglobulin heavy chain $(I G H)$ gene rearrangements was also reportedly useful for diagnosing pulmonary lymphoma. The aim of this prospective multicenter study was to evaluate the yet unknown diagnostic potential of combined detection of MALT1 translocations and clonality using BALF.

\section{Methods}

We analyzed B- and T-cell clonality based on IGH and T-cell receptor $(T C R)$ rearrangements together with MALT1 translocations using BALF of patients with clinically suspected pulmonary lymphomas.

\section{Results}

In total, 39 patients were evaluated and categorized into three groups: B-cell lymphoma, lymphoproliferative disorders, and other diseases. Detection of IGH rearrangements showed sensitivity and specificity of $88.9 \%$ and $90.0 \%$, respectively, for B-cell lymphoma diagnosis. TCR rearrangements were not observed in patients with B-cell lymphomas. The presence of $I G H$ rearrangements together with the absence of $T C R$ rearrangements showed $96.0 \%$ specificity for the diagnosis of B-cell lymphoma. The sensitivity and specificity of MALT1 translocations for diagnosing MALT lymphoma were $28.6 \%$ and $100 \%$, respectively.

\section{Conclusion}

The combined detection of lymphocyte clonality and MALT1 translocations using BALF is suitable for screening and diagnosis of B-cell lymphomas. Analysis of specific genes such as MALT1 should improve the precision of B-cell lymphoma diagnosis.

\section{Background:}

Pulmonary lymphomas account for $0.5-1 \%$ of all pulmonary malignancies (1-3). Among 1,500 patients with lung cancer, $1.7 \%$ were diagnosed with primary pulmonary lymphoma and $2.7 \%$ - with secondary involvement of the lung by lymphoma (4). Mucosa-associated lymphoid tissue (MALT) lymphoma is a low-grade B-cell malignancy representing the most frequently diagnosed type of pulmonary lymphomas 
$(3,5)$; other types include diffuse large B-cell lymphomas and T-cell lymphomas. Owing to their relative rarity and difficult detection, pulmonary lymphomas are challenging to manage and their diagnostic strategy is not well established.

Minimally invasive techniques such as bronchoscopy and computed tomography (CT)-guided lung biopsy are often employed for diagnosing lung lesions to avoid more invasive surgical interventions (3). However, tissue samples obtained via transbronchial lung biopsy (TBLB) or CT-guided lung biopsy are small and contain a mixture of infiltrates, including neoplastic lymphoid cells and other inflammatory cells (3). These problems complicate the diagnosis of pulmonary lymphomas, necessitating diagnostic surgical interventions $(1,3,4,6-8)$ in $55.7-100 \%$ of patients $(1,6,8-10)$. Therefore, a less invasive diagnostic procedure is desirable.

Lymphocytic alveolitis is indicative of pulmonary lymphoma and can be detected by analyzing bronchoalveolar lavage fluid (BALF) $(3,11)$. In most lymphoproliferative disorders, T- and B-lymphocytes constitute $>90 \%$ and $<10 \%$ of the total BALF lymphocytes, respectively. In pulmonary B-cell lymphomas, bronchoalveolar B-lymphocyte levels increase to more than $10 \%(3,12-14)$, and the clonality of Blymphocytes, along with rearrangements of the immunoglobulin heavy chain-encoding $I G H$ gene, may contribute to the diagnosis. Rearrangements of the T-cell receptor-encoding TCR gene have been reported to indicate T-cell lymphomas (15-19); however, the diagnostic utility of analyzing this biomarker in BALF remains unclear. Rearrangements in the MALT1 gene located on chromosome 18q21 and encoding MALT lymphoma translocation protein 1 are specific for MALT lymphomas; they include IGH/MALT1 translocation and API2/MALT1 fusion between the API2 (apoptosis inhibitor 2) and MALT1 genes (20, 21). We have previously shown that the detection of MALT1 translocations in BALF cells by fluorescence in situ hybridization (FISH) is specific for pulmonary MALT lymphoma and could be used for diagnostic purposes (22).

In this study, we analyzed the feasibility of using BALF for combined detection of lymphocyte clonality based on IGH and TCR rearrangements as well as MALT1 translocations to diagnose pulmonary lymphomas.

\section{Methods:}

\subsection{Study design}

This prospective multicenter cohort study was conducted in the University of Occupational and Environmental Health and six related hospitals (Nagasaki University Hospital, Fukuoka University Hospital, Kokura Kinen Hospital, Oita University Hospital, University of Miyazaki Hospital, and Wakamatsu Hospital of University of Occupational and Environmental Health) in Japan. The study was performed according to the Declaration of Helsinki and approved by the Human and Animal Ethics Review Committee of the University of Occupational and Environmental Health, Japan (Approval number: 
H25-109 and H27-094) and by each institutional review board. All adult participants provided written informed consent to participate in this study.

\subsection{Patients' clinical and laboratory characteristics}

Patients suspected to have pulmonary lymphoma based on their clinical history, laboratory data, and chest high-resolution CT (HRCT) results and admitted to our hospitals from October 2013 to March 2018 were enrolled. For all patients, the data regarding sex, age, smoking history, levels of serum lactate dehydrogenase (LDH) and soluble interleukin 2 receptor (sIL-2R), chest HRCT results, pathological findings, and final diagnosis were collected and analyzed. According to a previous report on the patternbased classification of pulmonary lesions involved in MALT lymphoma formation (6), chest HRCT findings were categorized into four types: 1) lung nodule and/or ground glass opacity, 2) lung mass and/or airspace consolidation, 3) peribronchial thickening and cyst, and 4) hilar and/or mediastinal lymphadenopathy. Lymphomas were diagnosed and classified according to the 2016 revision of the World Health Organization classification of lymphoid neoplasms (23).

\subsection{BALF collection}

BALF was obtained using flexible bronchofiberscopy. After adequate local anesthesia with lidocaine, three $50 \mathrm{~mL}$ fractions of sterile saline were instilled into the most extensively involved pulmonary segment determined by chest HRCT, gently retrieved using a suction syringe, and placed into sterile containers for microbiological and cytological examinations. BALF samples $(30 \mathrm{~mL})$ were stored at $4^{\circ} \mathrm{C}$ until analysis of $I G H$ and $T C R$ rearrangements $(15 \mathrm{~mL})$ and $M A L T 1$ translocations $(15 \mathrm{~mL})$. Patients from whom sufficient BALF volumes could not be recovered were excluded from the study.

\subsection{Detection of IGH and TCR rearrangements and MALT1 translocations}

IGH and TCR rearrangements in BALF lymphocytes were examined using IdentiClone® IGH and TCRB Gene Clonality Assays (Invivoscribe Technologies, Inc., San Diego, CA, USA) $(24,25)$, which detect $\mathrm{VH}(\mathrm{FR} 1) / \mathrm{JH}, \mathrm{VH}(\mathrm{FR} 2) / \mathrm{JH}, \mathrm{VH}(\mathrm{FR} 3) / \mathrm{JH}, \mathrm{DH} 1-6 / \mathrm{JH}$, and $\mathrm{DH} 7 / \mathrm{JH}$ regions in $/ G H$ and $\mathrm{V} \beta / \mathrm{J} \beta 1, \mathrm{~V} \beta / \mathrm{J} \beta 2$, and $D \beta / J \beta$ regions in $T C R B$ by polymerase chain reaction (PCR) and capillary electrophoresis. When the electrophoresis pattern showed one distinct peak on a low background, which was higher than the peak of positive control (monoclonal pattern), the sample was considered positive (Fig. 1A), whereas samples with peaks lower than that of positive control or those with several higher peaks without individualization of one peak (oligoclonal pattern) were considered negative (13) (Fig. 1B). When the monoclonal pattern was observed in at least one of IGH or TCR regions, the gene was considered to have rearrangement.

MALT1 translocations were detected using FISH with the MALT1 probe (Vysis MALT1 Break Apart FISH Probe Kit, Abbott Japan, Tokyo, Japan) consisting of a 460-kb 5'-end fragment labeled with SpectrumOrange and a 660-kb 3'-end fragment labeled with SpectrumGreen, as previously described (22, 26-28). Cells with MALT1 translocations would show split orange and green signals (Fig. 1D), whereas normal cells would show fused orange-green signals (Fig. 1E). Hybridized signals for each probe were 
evaluated in the interphase nuclei of 1,000 cells and positive cut-off values were set at $1.2 \%$ based on the analysis of blood samples from 30 healthy subjects performed by LSI Medience Corporation (Tokyo, Japan).

\subsection{Statistical analyses}

The data are presented as the median (range) or the number of patients (\%). All calculations were performed using the StatFlex software version 6 (Artech, Osaka, Japan). Continuous variables were compared by the Mann-Whitney U-test with Kruskal-Wallis test, and categorical variables - by chi-square or Fisher's exact tests as appropriate. $P<0.05$ was considered to indicate statistical significance.

\section{Results:}

\subsection{Patients' characteristics}

In total, 46 patients were enrolled in the study; however, 5 patients with unconfirmed final diagnoses and 2 with BALF samples inadequate for molecular examination were excluded (Fig. 2). The 39 patients included for further analysis were divided into the B-cell lymphoma group (9 patients: 7 with MALT, 1 with lymphoplasmacytic, and 1 with follicular lymphomas), the lymphoproliferative disorder (LPD) group (12 patients: 5 with interstitial lung diseases due to Sjögren's syndrome, 4 with methotrexate (MTX)-related lymphoproliferative disorders, 2 with sarcoidosis, and 1 with multicentric Castleman's disease), and the "Others" group (18 patients: 6 with infectious diseases, 5 with interstitial lung diseases, 3 with lung cancer, 1 with vasculitis, 1 with lung involvement in multiple myeloma, 1 with relapsing polychondritis, and 1 with granulomatous lung disease). None of the patients had T-cell lymphomas. The demographic and baseline characteristics of patients in each group are shown in Table 1. There were no significant differences among the groups in age, sex, smoking status, and serum levels of LDH and sIL-2R; median serum sIL-2R levels were higher than normal in all groups. In regard to chest HRCT findings, there was no significant difference among the groups in the ratio of hilar and/or mediastinal lymphadenopathy to multiple cysts; however, the values of lung nodule and/or ground glass opacity were significantly lower, whereas the lung mass and/or airspace consolidation were significantly higher in the B-cell lymphoma group than in the LPD group. The median percentage of lymphocytes among BALF cells was increased (more than $10 \%$ ) in all groups. TBLB was performed in $100 \%, 91.7 \%$, and $83.3 \%$, and surgical lung biopsy (SLB) - in $33.1 \%, 16.7 \%$, and $5.5 \%$ of patients in the B-cell lymphoma, LPD, and other groups, respectively. 
Table 1

Demographic and baseline characteristics of patients

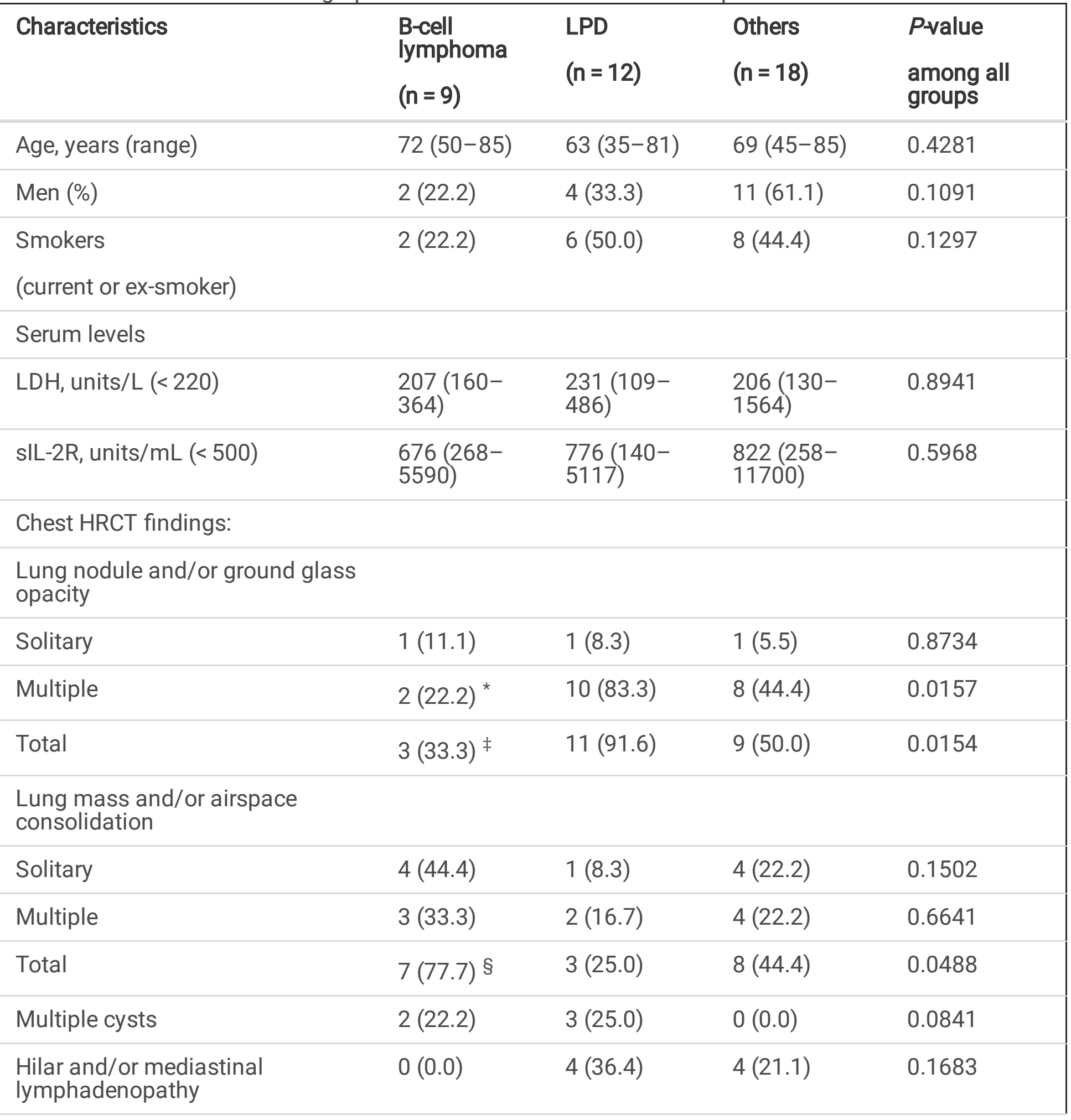

The data are presented as the median (range) or number (\%).

${ }^{*} p=0.0051,{ }^{\ddagger} p=0.0050$, and $\S p=0.0166$ for B-cell lymphoma versus LPD

Abbreviations: HRCT, high-resolution computer tomography; LDH, lactate dehydrogenase; LPD, lymphoproliferative disorder; sIL-2R, soluble interleukin-2 receptor; SLB, surgical lung biopsy; TBLB, transbronchial lung biopsy; TBNA, transbronchial needle aspiration. 


\begin{tabular}{|c|c|c|c|c|}
\hline Characteristics & $\begin{array}{l}\text { B-cell } \\
\text { lymphoma } \\
(n=9)\end{array}$ & $\begin{array}{l}\text { LPD } \\
(n=12)\end{array}$ & $\begin{array}{l}\text { Others } \\
(n=18)\end{array}$ & $\begin{array}{l}P \text {-value } \\
\text { among all } \\
\text { groups }\end{array}$ \\
\hline \multicolumn{5}{|l|}{ Bronchoalveolar lavage } \\
\hline Macrophages (\%) & $\begin{array}{l}62.0(38.0- \\
88.4)\end{array}$ & $\begin{array}{l}67.4(20.9- \\
86.3)\end{array}$ & $68.7(0-96.0)$ & 0.8614 \\
\hline Lymphocytes (\%) & $\begin{array}{l}24.0(8.3- \\
40.0)\end{array}$ & $\begin{array}{l}18.7(8.3- \\
76.5)\end{array}$ & $\begin{array}{l}18.3(3.0- \\
40.0)\end{array}$ & 0.3428 \\
\hline Neutrophils (\%) & $\begin{array}{l}4.8(1.0- \\
44.0)\end{array}$ & $\begin{array}{l}2.0(0.0- \\
31.5)\end{array}$ & $\begin{array}{l}7.3(0.0- \\
49.0)\end{array}$ & 0.2111 \\
\hline Eosinophils (\%) & $0.0(0.0-3.0)$ & $\begin{array}{l}1.7(0.0- \\
12.6)\end{array}$ & $\begin{array}{l}1.0(0.0- \\
29.0)\end{array}$ & 0.6291 \\
\hline Basophils (\%) & $0.0(0.0-0.0)$ & $0.0(0.0-1.7)$ & $0.0(0.0-0.0)$ & 0.3679 \\
\hline \multicolumn{5}{|l|}{ Lung biopsy } \\
\hline TBLB & $9(100)$ & $11(91.7)$ & 15 (83.3) & 0.3906 \\
\hline CT-guided & $0(0.0)$ & $0(0.0)$ & $1(5.5)$ & 0.5495 \\
\hline SLB & $3(33.3)$ & $2(16.7)$ & $1(5.5)$ & 0.1671 \\
\hline \multicolumn{5}{|l|}{ Other biopsies } \\
\hline Lip & $1(11.1)$ & $2(16.7)$ & $0(0.0)$ & 0.2221 \\
\hline Bone & $1(11.1)$ & $0(0.0)$ & $0(0.0)$ & 0.1808 \\
\hline TBNA & $0(0.0)$ & $2(16.7)$ & $1(5.5)$ & 0.0933 \\
\hline Lymph node & $2(22.2)$ & $3(25.0)$ & $2(11.1)$ & 0.5804 \\
\hline Subcutaneous nodule & $0(0.0)$ & $1(8.3)$ & $0(0.0)$ & 0.3152 \\
\hline \multicolumn{5}{|c|}{ The data are presented as the median (range) or number (\%). } \\
\hline \multicolumn{5}{|c|}{${ }^{*} p=0.0051,{ }^{\ddagger} p=0.0050$, and $\S^{\S} p=0.0166$ for B-cell lymphoma versus LPD } \\
\hline \multicolumn{5}{|c|}{$\begin{array}{l}\text { Abbreviations: HRCT, high-resolution computer tomography; LDH, lactate dehydrogenase; LPD, } \\
\text { lymphoproliferative disorder; sIL-2R, soluble interleukin-2 receptor; SLB, surgical lung biopsy; TBLB, } \\
\text { transbronchial lung biopsy; TBNA, transbronchial needle aspiration. }\end{array}$} \\
\hline
\end{tabular}

\subsection{IGH and TCR rearrangements}

The total rate of $I G H$ rearrangement was significantly higher in the B-cell lymphoma group (88.9\%) than in the LPD group $(16.7 \%, p<0.01)$ and the other group $(5.5 \%, p<0.01)$ (Fig. 3A). Rearrangements in specific IGH regions $(\mathrm{VH}(\mathrm{FR} 1) / \mathrm{JH}, \mathrm{VH}(\mathrm{FR} 2) / \mathrm{JH}, \mathrm{VH}(\mathrm{FR} 3) / \mathrm{JH}, \mathrm{DH} 1-6 / \mathrm{JH}$, and $\mathrm{DH} 7 / \mathrm{JH})$ are shown in Supplementary Figure S1 and Table S1. The sensitivity, specificity, and positive and negative predictive 
values of the total IGH rearrangement rate for the diagnosis of B-cell lymphoma were $88.9 \% 90.0 \%$, $72.7 \%$, and $96.4 \%$, respectively.

TCR rearrangements in BALF cells were evaluated in 6 of 8,9 of 12, and 15 of 18 patients with B-cell lymphoma, LPD, and other diseases, respectively, and the total rearrangement rates were calculated as $0.0 \%, 33.3 \%$ and $13.3 \%$, respectively (Fig. 3B, Supplementary Figure S1and Table S2). Although the differences between the groups were not statistically significant, the results indicated that all patients with B-cell lymphomas were negative for TCR rearrangements in BALF cells. The sensitivity, specificity, and positive and negative predictive values of the combination of $I G H$ rearrangement-positive and TCR rearrangement-negative results for the diagnosis of B-cell lymphoma were $100 \%, 96.0 \%, 85.7 \%$, and $100 \%$, respectively.

\subsection{MALT1 translocations}

Analysis of MALT1 translocation frequencies in each group indicated that $28.6 \%(2 / 7)$ patients with MALT lymphoma were positive, whereas all other patients, including those with non-MALT B-cell lymphoma, were negative for MALT1 translocation (Fig. 4A). The sensitivity and specificity of MALT1 translocation detection for MALT lymphoma diagnosis were $28.6 \%$ and $100 \%$, respectively. The rate of MALT1 translocations among patients with MALT lymphoma was significantly higher than that in the other group $(p<0.05)$. The proportions of MALT1 translocation-positive lymphocytes in BALF were $30.5 \%$ and $10.0 \%$ in the 2 positive patients (Fig. 4B) who also had IGH rearrangements (Table 2). These 2 patients, as well as 6 of 9 patients with B-cell lymphomas (66.7\%), could be diagnosed without SLB. 
Table 2

Procedures to diagnose B-cell lymphomas

\begin{tabular}{|c|c|c|c|c|}
\hline \multirow[t]{2}{*}{ Lymphoma type } & \multirow[t]{2}{*}{ Biopsy type } & \multicolumn{3}{|c|}{ Findings in BALF } \\
\hline & & $\begin{array}{l}\text { IGH } \\
\text { rearrangement }\end{array}$ & $\begin{array}{l}T C R \\
\text { rearrangement }\end{array}$ & $\begin{array}{l}\text { MALT1 } \\
\text { translocation }\end{array}$ \\
\hline MALT & TBLB & Positive & NA & Positive \\
\hline MALT & TBLB & Positive & NA & Positive \\
\hline MALT & TBLB, SLB & Positive & Negative & Negative \\
\hline MALT & TBLB, SLB & Positive & Negative & Negative \\
\hline MALT & $\begin{array}{l}\text { TBLB, LN } \\
\text { biopsy }\end{array}$ & Positive & Negative & Negative \\
\hline MALT & TBLB, SLB & Positive & Negative & Negative \\
\hline MALT & TBLB & Positive & Negative & Negative \\
\hline Follicular & $\begin{array}{l}\text { TBLB, bone } \\
\text { biopsy }\end{array}$ & Positive & Negative & Negative \\
\hline Lymphoplasmacytic & $\begin{array}{l}\text { TBLB, LN } \\
\text { biopsy }\end{array}$ & Negative & NA & Negative \\
\hline \multicolumn{5}{|c|}{$\begin{array}{l}\text { BALF, bronchoalveolar lavage fluid; LN, lymph node; SLB, surgical lung biopsy; MALT, mucosa- } \\
\text { associated lymphoid tissue; IGH, immunoglobulin heavy chain-encoding gene; TCR, T-cell receptor- } \\
\text { encoding gene; MALT1, MALT lymphoma translocation gene } 1 ; \text { TBLB, transbronchial lung biopsy; NA, } \\
\text { not available }\end{array}$} \\
\hline
\end{tabular}

\section{Discussion:}

This is the first study that analyzed the diagnostic utility of IGH and TCR rearrangements in clonality analyses in addition to MALT1 translocation in BALF of patients with clinically suspected pulmonary lymphoma. In our study, the sensitivity and specificity of $I G H$ rearrangement results for B-cell lymphoma diagnosis were $88.9 \%$ and $90.0 \%$, respectively. All patients with B-cell lymphoma were negative for $T C R$ rearrangements, and the specificity of combined IGH rearrangement-positive and TCR rearrangementnegative results for the B-cell lymphomas diagnosis was $96.0 \%$. The sensitivity and specificity of MALT1 translocation testing for MALT lymphoma diagnosis were $28.6 \%$ and $100 \%$, respectively. These findings suggest that the combined detection of IGH and TCR rearrangements in BALF cells is useful for the screening and diagnosis of B-cell lymphomas and that analysis of specific genes such as MALT1 can improve the diagnostic accuracy.

It is difficult to detect pulmonary lymphomas using small tissue samples obtained by TBLB or CT-guided lung biopsy, and $55.7-100 \%$ of patients need surgical interventions for definitive diagnosis $(1,6,8-10)$. In a retrospective review of 24 patients with pulmonary lymphomas, only 3 of 13 patients with pulmonary MALT lesions underwent complete surgical resection, whereas the others received chemotherapy (9). In 
another retrospective study of 61 patients with pulmonary MALT lymphomas, no differences were observed in the time to progression between patients who underwent invasive surgical resection and those who received chemotherapy (8). Thus, the development of molecular methods that allow making accurate diagnosis using small tissue samples is essential to help avoid invasive procedures. In the present study, $66.7 \%$ of patients with B-cell lymphomas were diagnosed without SLB, including 2 patients positive for both $1 G H$ rearrangements and MALT1 translocations, indicating that the combined detection of these genetic aberrations can provide a more accurate diagnosis through a less invasive procedure.

The usefulness of detecting IGH rearrangements in BALF cells has already been assessed in several studies. Thus, it was shown that PCR analysis of $I G H$ rearrangements in patients with B-cell pulmonary lymphomas was sensitive (6 of 7 patients) and specific (0 of 9 control individuals) (12). Positive results were also obtained in $83 \%$ and $82 \%$ of patients with B-cell and MALT lymphomas at $90 \%$ and $97 \%$ specificity, respectively $(13,14)$. In the present study, we observed a similar sensitivity $(88.9 \%)$ and specificity $(90.0 \%)$ of $I G H$ rearrangement detection for B-cell lymphoma diagnosis. We also analyzed TCR rearrangements using the $T C R B$ clonal assay, which is considered one of the standard lymphoma diagnostic tools in Europe, detecting clonal TCRB rearrangements in 39.3-91.0\% of T-cell lymphomas and in 3.8-16.0\% of B-cell lymphomas (16-19). In the present study, TCR rearrangements were absent in BALF cells of patients with B-cell lymphomas but present in $33.3 \%$ and $13.3 \%$ of patients with LPD and other diseases, respectively. Unfortunately, we did not analyze patients with T-cell pulmonary lymphoma because of its rarity. Our results revealed that the presence of $I G H$ rearrangements combined with the absence of $T C R$ rearrangements had $96 \%$ specificity for the diagnosis of B-cell lymphoma. Unexpectedly, $75 \%$ of patients with MTX-related LPD exhibited clonal patterns (Supplementary Table S2), suggesting that TCR rearrangements may also be useful for diagnosing MTX-related LPD. Further studies are needed to evaluate the utility of TCR rearrangement testing in BALF cells for pulmonary T-cell lymphoma diagnosis.

Chromosomal translocations associated with MALT lymphoma include API2/MALT1, IGH/MALT1, $B C L 10 / I G H$, and trisomy 3 and $18(14,23,27)$. The API2/MALT1 translocation was detected in $30-70 \%$ of MALT lymphoma lung tissues obtained by SLB $(20,21,27-29)$, whereas the IGH/MALT1 translocation was revealed in $6-10 \%$ of patients with MALT lymphoma $(27,28)$. The probe for MALT1 translocation used in the present study detected both API2/MALT1 and IGH/MALT1 translocations, and the MALT1 translocation rate in patients with pulmonary MALT lymphomas observed here (28.6\%) was consistent with previous reports $(20,21,27-29)$. Owing to its $100 \%$ specificity, the FISH-based detection of MALT1 rearrangements in BALF cells would significantly improve the diagnostic accuracy for MALT lymphomas. Furthermore, the increased detection of genetic aberrations frequently observed in B-cell lymphomas, including $B C L 2, B C L 6, I G H$, and MALT1 translocations, should promote the development of lymphoma gene panels for BALF in the era of next-generation sequencing.

Besides clonality and gene translocation testing, phenotyping using various markers such as cluster of differentiation (CD) can be employed to diagnose lymphomas (30). For clonal analyses by PCR, the detection of rearrangements in heavy and light immunoglobulin chain genes (IGH, IGK, and IGL) and TCR 
genes (TCRB, TCRD, and TCRG) is a standard approach used in Europe to diagnose B- and T-cell lymphomas $(16,17,19,31)$; however, the combination of these gene rearrangements in BALF cells has not been analyzed. The detection of both IGH rearrangements and CD expression in BALF cells has been shown to aid in diagnosing pulmonary B-cell lymphoma: it revealed B-cell clonality as well as an increase in B-cell (CD19- or CD20-positive) lymphocytes to over $10 \%$ of total BALF lymphocytes $(3,12-14)$. Collectively, these data suggest that the combined analysis of disease markers such as clonality, gene translocations, and CD expression in BALF should aid in diagnosing pulmonary lymphomas through a less invasive method.

\section{Conclusions}

In conclusion, we evaluated the utility of the combined detection of clonality and MALT1 translocations in BALF for the diagnosis of pulmonary lymphomas. Our results suggest that this combinatorial approach should help in identifying B-cell lymphomas through a less invasive method. Detection of additional genetic aberrations such as MALT1 translocations in BALF cells can further specify the type of pulmonary lymphoma. Future studies should explore other combinatorial tools such as phenotyping along with IGH/TCR rearrangements to screen for pulmonary lymphomas.

\section{Abbreviations}

API2, apoptosis inhibitor 2; BALF, bronchoalveolar lavage fluid; CD, cluster of differentiation; CT, computed tomography; FISH, fluorescence in situ hybridization; $\mathrm{HRCT}$, high-resolution $\mathrm{CT}$; IGH, immunoglobulin heavy chain; LDH, lactate dehydrogenase; LN, lymph node; LPD, lymphoproliferative disorder; MALT, mucosa-associated lymphoid tissue; MALT1, mucosa-associated lymphoid tissue lymphoma translocation gene 1; MTX, methotrexate; sIL-2R, soluble interleukin-2 receptor; SLB, surgical lung biopsy; TBLB, transbronchial lung biopsy; TCR, T-cell receptor; TCRB, TCR-beta gene.

\section{Declarations}

\section{ETHICS APPROVAL AND CONSENT TO PARTICIPATE}

The study was performed in accordance with the Declaration of Helsinki and was approved by the Human and Animal Ethics Review Committee, of the University of Occupational and Environmental Health, Japan (Approval numbers: H25-109 and H27-094) and by each institutional review board. All adult participants provided written informed consent to participate in this study.

AVAILABILITY OF DATA AND MATERIALS: The data that support the findings of this study are available from the corresponding author upon reasonable request.

COMPETING INTERESTS: None 
FUNDING: This work was supported by JSPS KAKENHI (grant number 15K09201) and The Japanese Foundation for Research and Promotion of Endoscopy grant. It was also partially supported by the Practical Research Project for Rare Intractable Diseases, the Japan Agency for Medical Research and Development (AMED), and a grant from the Ministry of Health, Labour and Welfare of Japan awarded to the study group working on diffuse pulmonary disorders and scientific research on intractable diseases.

AUTHORS' CONTRIBUTIONS:T. Kido, H.M., and K.Y. were involved in the conceptualization process, and T. Kido was responsible for data curation and formal analysis. Investigations were performed by T. Kido, H. Ishimoto, H. Ishii, K.H., H.K., T. Kawanami., Y.S., H.Y., A.H., N.S., N.M., C.Y., M.F., M.N., J.K., and K.Y. The methodology to be used was decided by T. Kido and K.Y. T. Kido, H.M., and K.Y. were responsible for project administration. T. Kido, N.S., and K.Y. wrote the original of the manuscript. T. Kido, H. Ishimoto, H. Ishii, K.H., H.K., T. Kawanami, Y.S., H.Y., A.H., N.S., N.M., C.Y., M.F., M.N., J.K., and K.Y. reviewed and edited the manuscript. All the authors have read and approved the final manuscript.

ACKNOWLEDGEMENTS: We thank LSI Medience Corporation for outsourcing the contract for the detection of IGH and TCR rearrangement and MALT1 translocation, and Mr. Osamu Takeyama and Ryouta Kukimoto (LSI Medience Corporation) for contributing to the outsourcing contract agreement. We would also like to thank Editage (www.editage.com) for English language editing.

\section{References}

1. Ferraro P, Trastek VF, Adlakha H, Deschamps C, Allen MS, Pairolero PC. Primary non-Hodgkin's lymphoma of the lung. Ann Thorac Surg. 2000;69:993-7.

2. Cardenas-Garcia J, Talwar A, Shah R, Fein A. Update in primary pulmonary lymphomas. Curr Opin Pulm Med. 2015;21:333-7.

3. Borie R, Wislez M, Antoine M, Copie-Bergman C, Thieblemont C, Cadranel J. Pulmonary mucosaassociated lymphoid tissue lymphoma revisited. Eur Resp J. 2016;47:1244-60.

4. William J, Variakojis D, Yeldandi A, Raparia K. Lymphoproliferative neoplasms of the lung: a review. Arch Patho Lab Med. 2013;137:382-91.

5. Fiche M, Caprons F, Berger F, Galateau F, Cordier J-F, Loire R, Diebold J. Primary pulmonary nonHodgkin's lymphomas. Histopathology 1995;26:529-37.

6. Ahmed S, Kussick SJ, Siddiqui AK, Bhuiya TA, Khan A, Sarewitz S, Steinberg H, Sison CP, Rai KR. Bronchial-associated lymphoid tissue lymphoma: a clinical study of a rare disease. Eur $J$ Cancer 2004;40:1320-6.

7. Bae YA, Lee KS, Han J, Ko YH, Kim BT, Chung MJ, Kim TS. Marginal zone B-cell lymphoma of bronchus-associated lymphoid tissue: imaging findings in 21 patients. Chest 2008;133:433-40.

8. Oh SY, Kim WS, Kim JS, Kim SJ, Kwon H, Lee DH, Won JH, Hwang IG, Kim MK, Lee SI, Chae YS, Yang D, Lee G, Choi CW, Park J, Suh C. Pulmonary marginal zone B-cell lymphoma of MALT type-what is a prognostic factor and which is the optimal treatment, operation, or chemotherapy?: Consortium for improving survival of lymphoma (CISL) study. Ann Hematol. 2010;89:563-8. 
9. Kim JH, Lee SH, Park J, Kim HY, Lee SI, Park JO, Kim K, Kim WS, Jung CW, Park YS, Im YH, Kang WK, Lee MH, Park K, Han JH, Ko YH. Primary pulmonary non-Hodgkin's lymphoma. Jpn J Clin Oncol. 2004;34:510-4.

10. Graham BB, Mathisen DJ, Mark EJ, Takvorian RW. Primary pulmonary lymphoma. Ann Thorac Surg. 2005;80:1248-53.

11. Drent M, Wagenaar SS, Mulder PH, van Velzen-Blad H, Diamant M, van den Bosch JM. Bronchoalveolar lavage fluid profiles in sarcoidosis, tuberculosis, and non-Hodgkin's and Hodgkin's disease. An evaluation of differences. Chest 1994;105:514-9.

12. Philippe B, Delfau-Larue MH, Epardeau B, Autran B, Clauvel JP, Farcet JP, Couderc LJ. B-cell pulmonary lymphoma: gene rearrangement analysis of bronchoalveolar lymphocytes by polymerase chain reaction. Chest 1999;115:1242-7.

13. Zompi S, Couderc LJ, Cadranel J, Antoine M, Epardeau B, Fleury-Feith J, Popa N, Santoli F, Farcet JP, Delfau-Larue $\mathrm{MH}$. Clonality analysis of alveolar B lymphocytes contributes to the diagnostic strategy in clinical suspicion of pulmonary lymphoma. Blood 2004;103:3208-15.

14. Borie R, Wislez M, Antoine M, Fleury-Feith J, Thabut G, Crestani B, Monnet I, Nunes H, Delfau-Larue $\mathrm{MH}$, Cadranel J. Clonality and phenotyping analysis of alveolar lymphocytes is suggestive of pulmonary MALT lymphoma. Respir Med. 2011;105:1231-7.

15. Hodges E, Krishna MT, Pickard C, Smith JL. Diagnostic role of tests for T cell receptor (TCR) genes. J Clin Pathol. 2003;56:1-11.

16. van Krieken JH, Langerak AW, Macintyre EA, Kneba M, Hodges E, Sanz RG, Morgan GJ, Parreira A, Molina TJ, Cabeçadas J, Gaulard P, Jasani B, Garcia JF, Ott M, Hannsmann ML, Berger F, Hummel M, Davi F, Brüggemann M, Lavender FL, Schuuring E, Evans PA, White H, Salles G, Groenen PJ, Gameiro P, Pott CH, Dongen JJ. Improved reliability of lymphoma diagnostics via PCR-based clonality testing: report of the BIOMED-2 concerted action BHM4-CT98-3936. Leukemia 2007;21:201-6.

17. Evans PA, Pott C, Groenen PJ, Salles G, Davi F, Berger F, Garcia JF, van Krieken JH, Pals S, Kluin P, Schuuring E, Spaargaren M, Boone E, González D, Martinez B, Villuendas R, Gameiro P, Diss TC, Mills K, Morgan GJ, Carter GI, Milner BJ, Pearson D, Hummel M, Jung W, Ott M, Canioni D, Beldjord K, Bastard C, Delfau-Larue MH, van Dongen JJ, Molina TJ, Cabeçadas J. Significantly improved PCRbased clonality testing in B-cell malignancies by use of multiple immunoglobulin gene targets. Report of the BIOMED-2 concerted action BHM4-CT98-3936. Leukemia 2007;21:207-14.

18. Chen YL, Su IJ, Cheng HY, Chang KC, Lu CC, Chow NH, Ho CL, Huang W. BIOMED-2 protocols to detect clonal immunoglobulin and T-cell receptor gene rearrangements in B-and T-cell lymphomas in southern Taiwan. Leuk Lymphoma 2010;51:650-5.

19. Kim Y, Choi YD, Choi C, Nam JH. Diagnostic utility of a clonality test for lymphoproliferative diseases in Koreans using the BIOMED-2 PCR assay. Korean J Pathol. 2013;47:458-65.

20. Motegi M, Yonezumi M, Suzuki H, Suzuki R, Hosokawa Y, Hosaka S, Kodera Y, Morishima Y, Nakamura S, Seto M. API2-MALT1 chimeric transcripts involved in mucosa-associated lymphoid tissue type lymphoma predict heterogeneous products. Am J Pathol. 2000;156:807-12. 
21. Okabe M, Inagaki H, Ohshima K, Yoshino T, Li C, Eimoto T, Ueda R, Nakamura S. API2-MALT1 fusion defines a distinctive clinicopathologic subtype in pulmonary extranodal marginal zone B-cell lymphoma of mucosa-associated lymphoid tissue. Am J Pathol. 2003;162:1113-22.

22. Kido T, Yatera K, Noguchi S, Sakurai Y, Nagata S, Kozaki M, Tokuyama S, Ogoshi T, Kawanami T, Yoshii C, Mukae H. Detection of MALT1 gene rearrangements in BAL fluid cells for the diagnosis of pulmonary mucosa-associated lymphoid tissue lymphoma. Chest 2012;141:176-82.

23. Swerdlow SH, Campo E, Pileri SA, Harris NL, Stein H, Siebert R, Advani R, Ghielmini M, Salles GA, Zelenetz AD, Jaffe ES. The 2016 revision of the World Health Organization classification of lymphoid neoplasms. Blood 2016;127:2375-90.

24. van Dongen JJ, Langerak AW, Brüggemann M, Evans PA, Hummel M, Lavender FL, Delabesse E, Davi F, Schuuring E, García-Sanz R, van Krieken JH, Droese J, González D, Bastard C, White HE, Spaargaren M, González M, Parreira A, Smith JL, Morgan GJ, Kneba M, Macintyre EA. Design and standardization of PCR primers and protocols for detection of clonal immunoglobulin and T-cell receptor gene recombinations in suspect lymphoproliferations: report of the BIOMED-2 concerted action BMH4-CT98-3936. Leukemia 2003;17:2257-317.

25. Sandberg Y, van Gastel-Mol EJ, Verhaaf B, Lam KH, van Dongen JJ, Langerak AW. BIOMED-2 multiplex immunoglobulin/T-cell receptor polymerase chain reaction protocols can reliably replace Southern blot analysis in routine clonality diagnostics. J Mol Diagn. 2005;7:495-503.

26. Akagi T, Motegi M, Tamura A, Suzuki R, Hosokawa Y, Suzuki H, Ota H, Nakamura S, Morishima $Y$, Taniwaki M, Seto M. A novel gene, MALT1 at 18q21, is involved in $t(11 ; 18)(q 21 ; q 21)$ found in lowgrade B-cell lymphoma of mucosa-associated lymphoid tissue. Oncogene 1999;18:5785-94.

27. Streubel B, Simonitsch-Klupp I, Müllauer L, Lamprecht A, Huber D, Siebert R, Stolte M, Trautinger F, Lukas J, Püspök A, Formanek M, Assanasen T, Hermelink HK, Cerroni L, Raderer M, Chott A. Variable frequencies of MALT lymphoma-associated genetic aberrations in MALT lymphomas of different sites. Leukemia 2004;18:1722-6.

28. Remstein ED, Dogan A, Einerson RR, Paternoster SF, Fink SR, Law M, Dewald GW, Kurtin PJ. The incidence and anatomic site specificity of chromosomal translocations in primary extranodal marginal zone B-cell lymphoma of mucosa-associated lymphoid tissue (MALT lymphoma) in North America. Am J Surg Pathol. 2006;30:1546-53.

29. Yonezumi M, Suzuki R, Suzuki H, Yoshino T, Oshima K, Hosokawa Y, Asaka M, Morishima $Y$, Nakamura S, Seto M. Detection of AP12-MALT1 chimaeric gene in extranodal and nodal marginal zone B-cell lymphoma by reverse transcription polymerase chain reaction (PCR) and genomic long and accurate PCR analyses. Br J Haematol. 2001;115:588-94.

30. Harris NL, Stein H, Coupland SE, Hummel M, Favera RD, Pasqualucci L, Chan WC. New approaches to lymphoma diagnosis. Hematology Am Soc Hematol Educ Program 2001:194-220.

31. Droese J, Langerak AW, Groenen PJ, Brüggemann M, Neumann P, Wolvers-Tettero IL, van Altena MC, Kneba M, van Dongen JJ. Validation of BIOMED-2 multiplex PCR tubes for detection of TCRB gene rearrangements in T-cell malignancies. Leukemia 2004;18:1531-8. 
A
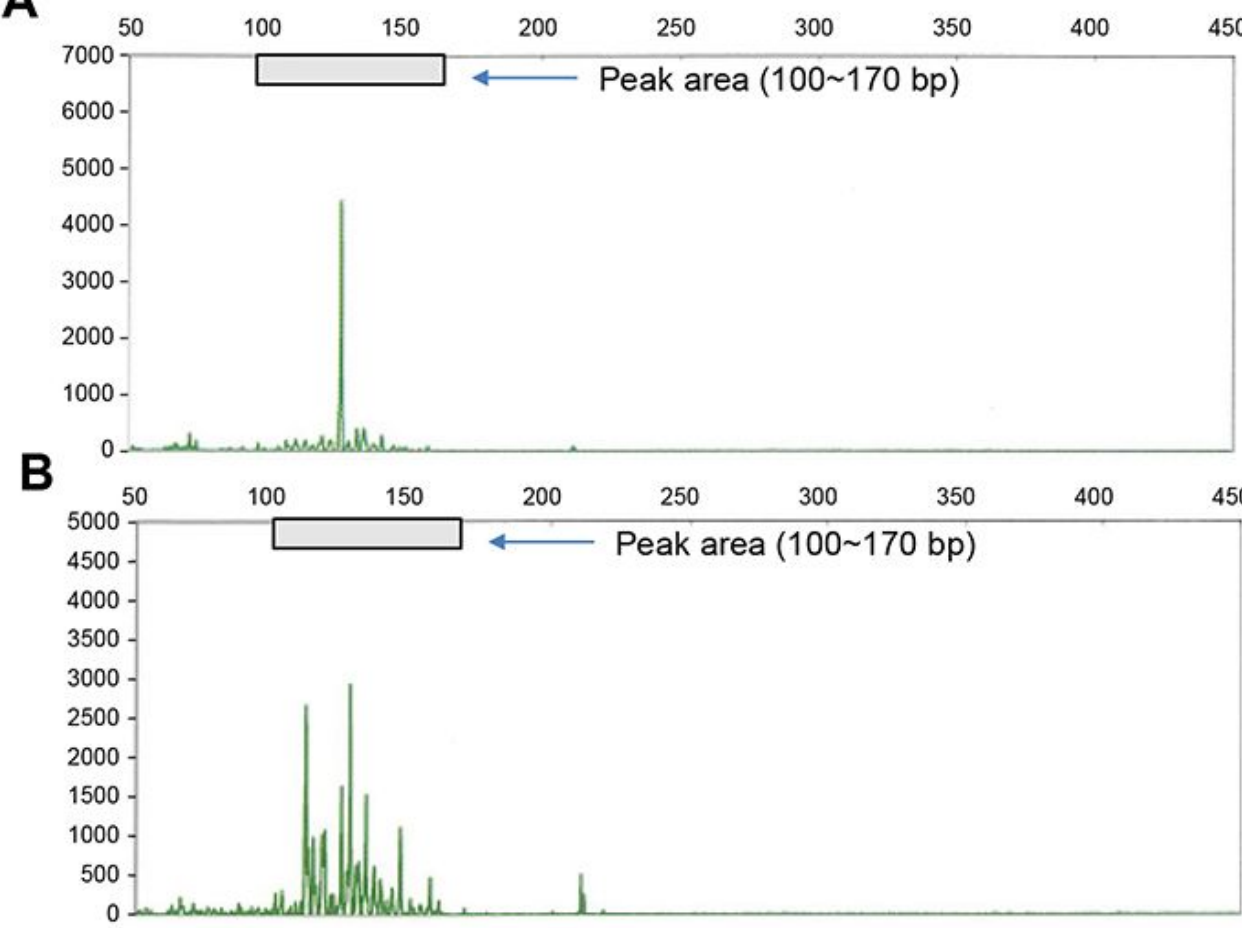

C

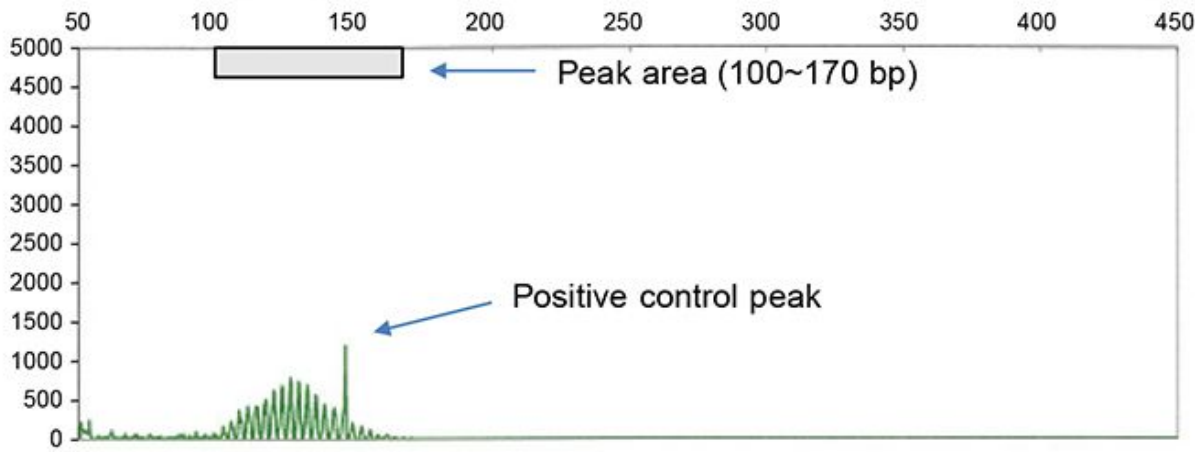

D

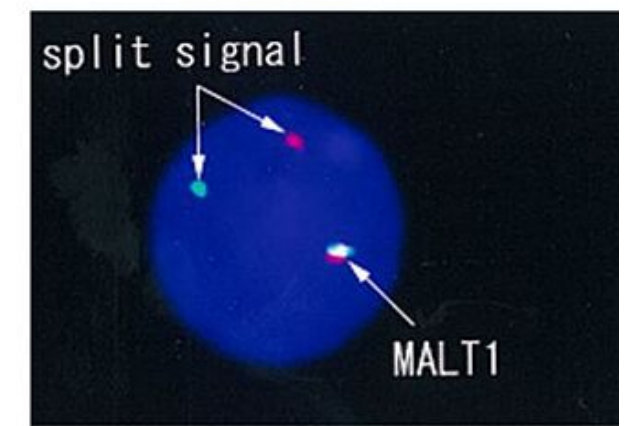

E

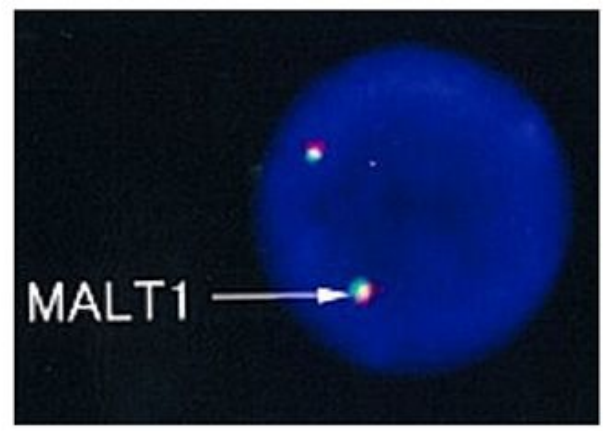

\section{Figure 1}

Examples of case analysis. (A, B) Positive results for the rearrangement of the $\mathrm{VH}(\mathrm{FR} 3) / \mathrm{JH}$ region in the IGH gene of BALF lymphocytes. A peak higher than that of the positive control is detected on a low background (monoclonal pattern; $A$ ) or several distinct peaks are seen on a polyclonal background (oligoclonal pattern; B). (C) A peak for the positive control. (D, E) Results of MALT1 translocation analysis by FISH. In case of MALT1 translocations, the orange and green signals are separated (D), whereas in a normal cell they are fused (E). 


\section{Patients suspected of having pulmonary lymphomas}

were subjected to BALF analyses $(n=46)$

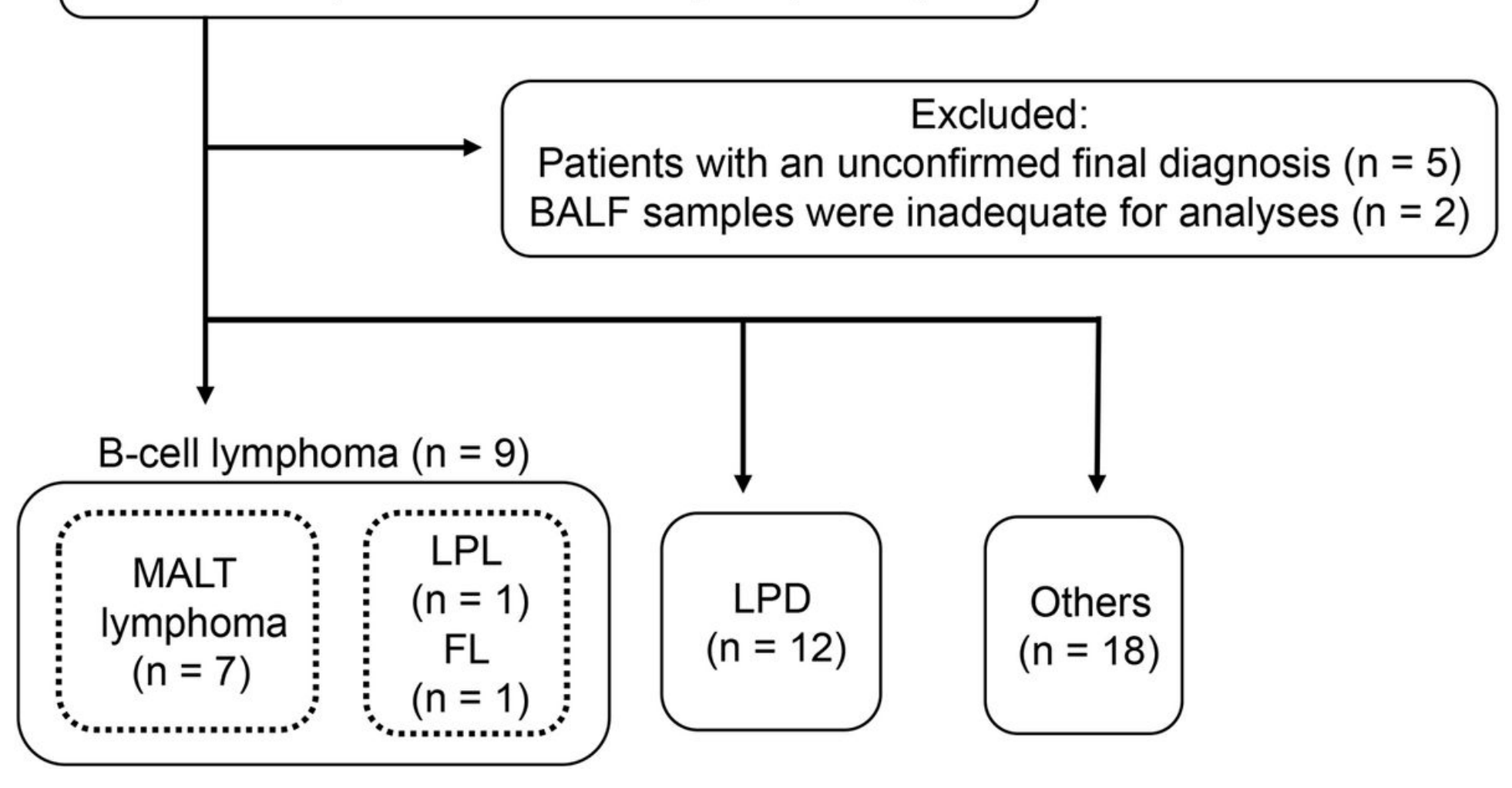

Figure 2

Flow chart of patient enrollment Abbreviations: BALF, bronchoalveolar lavage fluid; LPL, lymphoplasmacytic lymphoma; FL, follicular lymphoma; LPD, lymphoproliferative disorders; MALT, mucosa-associated lymphoid tissue; Others, other diseases. 
A
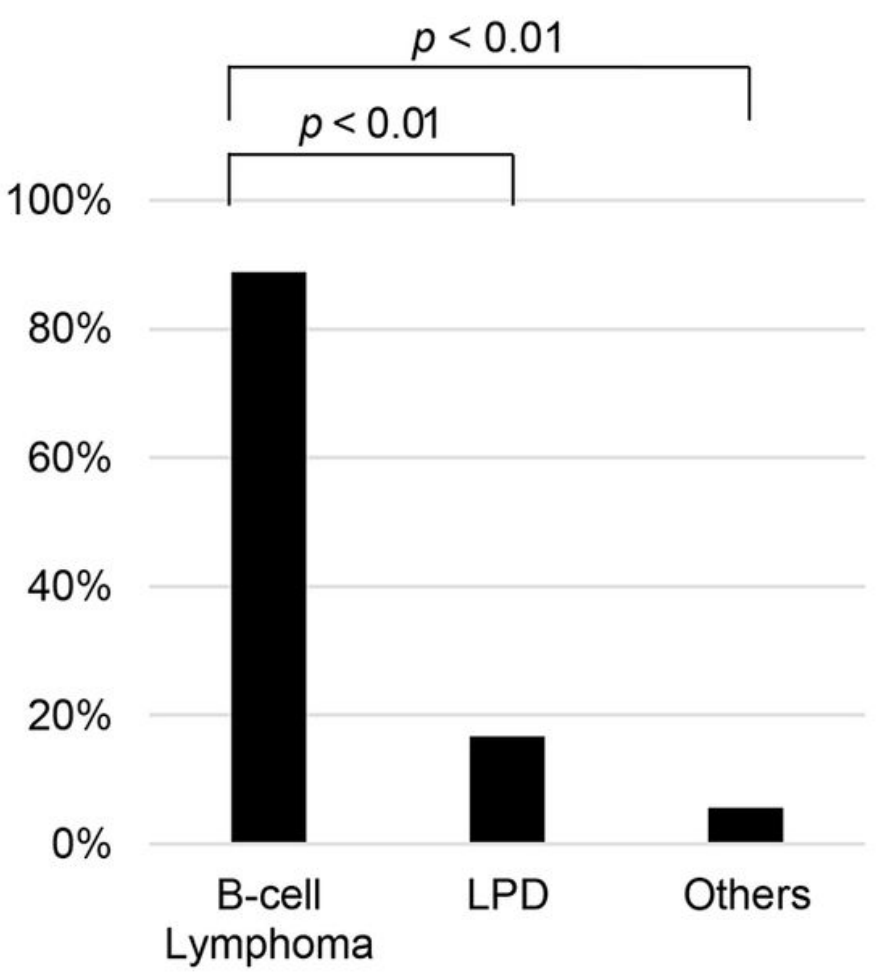

B

$100 \%$

$80 \%$

$60 \%$

$40 \%$

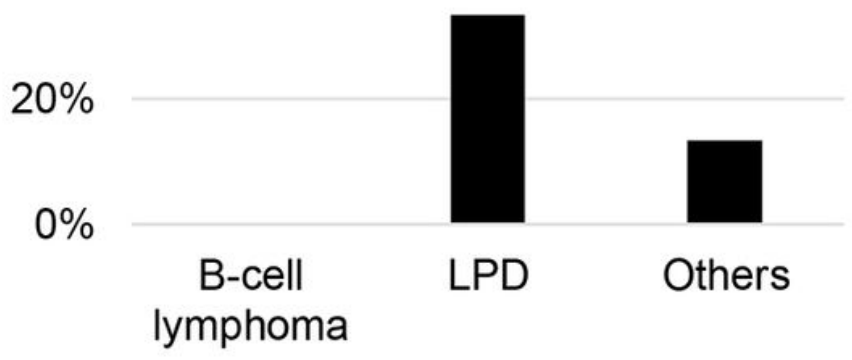

\section{Figure 3}

Clonality analysis in BALF. (A) Total IGH rearrangement rates (at least one positive region). (B) Total TCR rearrangement rates. LPD, lymphoproliferative disorder. 
A

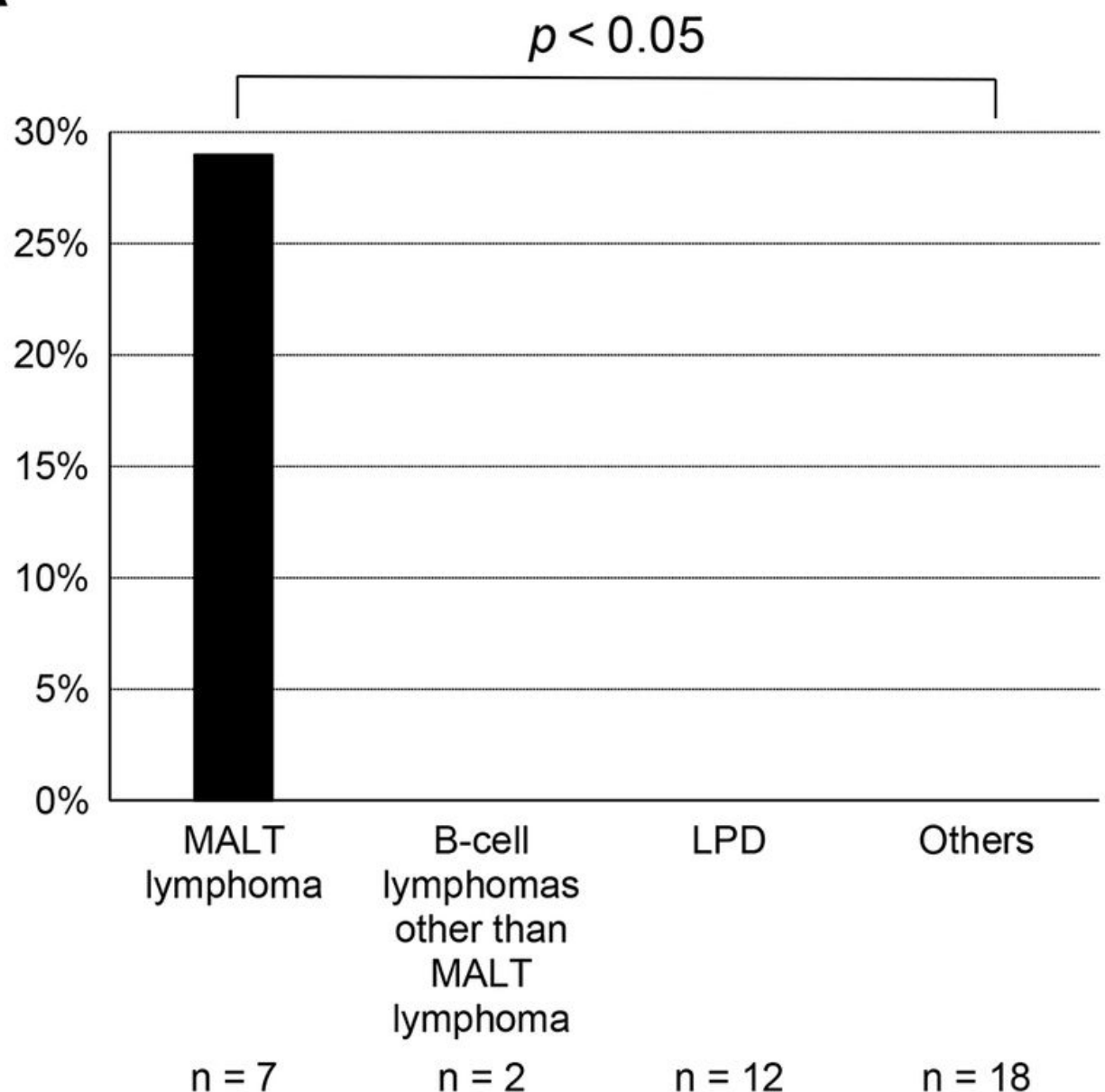

B

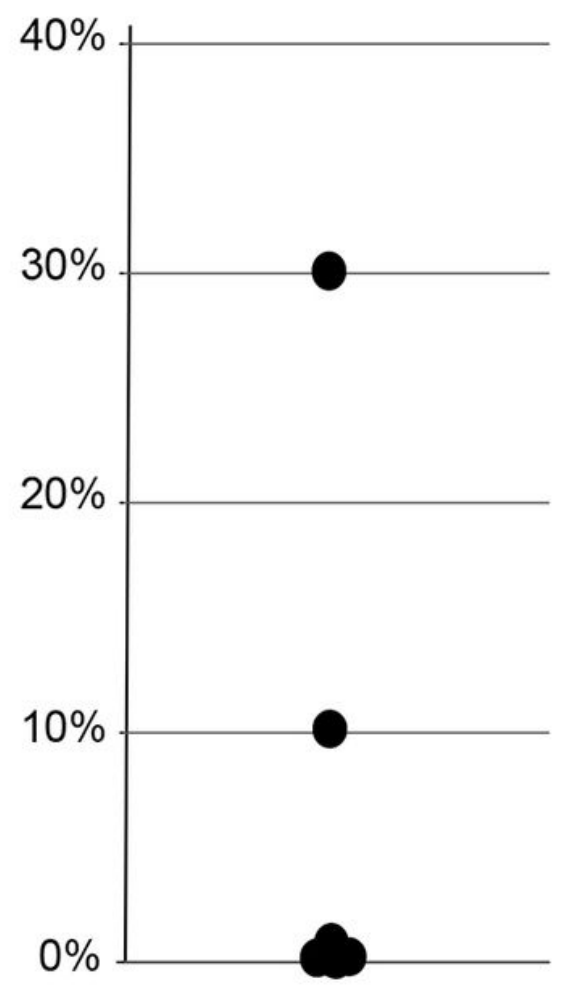

$\mathrm{n}=7$

Figure 4

MALT1 translocations in BALF cells. (A) MALT1 translocation frequency in each patient group. (B) The percentage of MALT1 translocation-positive lymphocytes among total BALF lymphocytes of patients with MALT lymphomas. MALT, mucosa-associated lymphoid tissue; LPD, lymphoproliferative disorder.

\section{Supplementary Files}

This is a list of supplementary files associated with this preprint. Click to download.

- SupplementaryInformation20210424.doc 